\title{
Peningkatan Pengetahuan Pengusaha Gamelan Desa Tihingan Kabupaten Klungkung
}

\author{
Ni Nyoman Sri Rahayu Damayanti ${ }^{1 *}$, I Gst. B Ngr. P. Putra ${ }^{2}$, I Gde Agung Wira Pertama ${ }^{3}$ \\ 1,2,3 Universitas Warmadewa
}

A R T I C L E I N F O

Article history:

Received 20 August 2019

Received in revised form

10 September 2019

Accepted 30 October 2019

Available online 30

November 2019

Kata Kunci:

Gamelan, Catatan

Keuangan, Word of Mouth

Keywords:

Gamelan, Financial Notes,

Word of Mouth.

\begin{abstract}
A B S T R A K
Gamelan Gunadi merupakan salah satu usaha yang bergerak di bidang pembuatan gamelan. Usaha yang terletak di Kabupaten Klungkung Kecamatan Tihingan, Propnsi Bali ini membuat berbagai macam jenis gamelan seperti gong, kecek, riyong, dan masih banyak yang lainnya. Mitra ini tidak hanya menerima pesanan gamelan, namun juga menerima pesanan perbaikan gamelan yang rusak. Terdapat beberapa kendala yang dihadapi mitra ketika melaksanakan operasional usahanya yaitu keterbatasan akan pengetahuan mengenai pencatatan keuangan serta keterbatasan dalam memasarkan usahanya. Hal tersebut yang mendorong penulis untuk melaksanakan pengabdian pada mitra ini. Terdapat beberapa kegiatan yang dilakukan untuk mengatasi kendala tersebut yaitu pelatihan penyusunan catatan keuangan cash on hand dan kas pada bank, serta melakukan penyuluhan strategi marketing yang efektif dan efisien serta mudah diimplementasikan oleh mitra. Kegiatan tersebut seluruhnya telah terlaksan. Setelah pelaksanaan penyuluhan, terdapat perubahan yang dirasakan oleh mitra yaitu mitra kini sudah bisa melakukan pencatatan keuangan sederhana sehingga yang bersangkutan mengetahui aliran kas usahanya baik yang cash on hand ataupun kas pada bank. Selain itu, mitra kini telah menguasai strategi pemasaran word of mouth yang diyakini mampu memperkenalkan usahanya serta mampu meningkatkan jumlah konsumen bagi usahanya.
\end{abstract}

\section{A B S T R A C T}

Gamelan Gunadi is one of the businesses engaged in the manufacture of gamelan. This business, which is located in Kabupaten Klungkung, Kecamatan Tihingan, Provinsi Bali, makes various types of gamelan such as gong, kecek, riyong, and many others. This partner not only accepts gamelan orders, but also receives damaged gamelan repair orders. There are several obstacles faced by partners when carrying out their business operations, namely limited knowledge of financial records and limitations in marketing their business. This is what drives the writer to carry out the service of this partner. There are several activities carried out to overcome these obstacles, training on the preparation of financial records of cash on hand and cash at the bank, as well as counseling marketing strategies that are effective and efficient and easily implemented by partners. These activities have all been carried out. After the implementation of the counseling, there were changes felt by the partners, namely the partners were now able to do simple financial records so that the concerned knew the cash flow of the business, either cash on hand or cash at the bank. In addition, partners have now mastered word of mouth marketing strategies that are believed to be able to introduce their businesses and be able to increase the number of consumers for their businesses.

\footnotetext{
* Corresponding author.

E-mail addresses: rahayudamayanti8@gmail.com (Ni Nyoman Sri Rahayu Damayanti)
} 


\section{Pendahuluan}

Negara Indonesia merupakan negara berkembang dengan tingkat pembangunan nasional nya yang begitu pesat. Pembangunan nasional di Indonesia pada saat ini menitik beratkan pembangunan nya pada bidang ekonomi. Pembangunan ekonomi merupakan suatu proses yang menyebabkan kenaikan pendapatan riil per kapita penduduk suatu negara dalam jangka panjang yang disertai oleh perbaikan sistem kelembagaan (Arsyad, 2001). Perkembangan perekonomian Indonesia pada saat ini bisa diukur oleh maraknya pembangunan pusat perdagangan. Pemerintah Indonesia telah menerapkan berbagai program penanggulangan kemiskinan beroperasi sesuai dengan kebijakan departemen terkait dan mereka tidak sepenuhnya terinetegrasi (Wulandari, 2017).

Budaya adalah suatu kompleks yang meliputi pengetahuan, keyakinan, seni, moral, adat istiadat serta kemampuan dan kebiasaan lain yang dimiliki manusia sebagai bagian dari masyarakat (Hawkins, 2012). Budaya lokal merupakan budaya yang dimiliki oleh suatu daerah dan menjadi identitas tersendiri bagi daerah tersebut serta menjadi warisan budaya bagi masyarakat setempat. Warisan budaya adalah produk atau hasil budaya fisik dari tradisi-tradisi yang berbeda dan prestasi-prestasi spiritual dalam bentuk nilai dari masa lalu yang menjadi elemen pokok dalam suatu kelompok atau bangsa (Davison dan Conville, 1991:2). Desa Tihingan yang bertempat di Kabupaten Klungkung, Provinsi Bali merupakan salah satu daerah yang memiliki warisan budaya gamelan. Di provinsi Bali, gamelan dapat dijadikan sebagai alat musik tradisional yang dipergunakan dalam acara sakral ataupun hiburan. Pada acara sakral, gamelan dipergunakan sebagai prasarana persembahyangan bagi masyarakat setempat dan pada acara hiburan dapat digunakan sebagai iring-iringan pada pagelaran kesenian. Desa Tihingan memiliki pengrajin usaha gamelan yang telah menjadi usaha turun-temurun masyarakat setempat.

Indonesia sangat banyak memiliki kebudayaan yang dapat dibanggakan, salah satunya adalah alat musik tradisional. Menurut Sedyawati musik tradisional adalah musik yang digunakan sebagai perwujudan dan nilai budaya, sesuai dengan tradisi (Isbat, 2014). Menurut Tumbijo Musik tradisional adalah seni budaya yang sejak lama turun temurun yang telah hidup dan berkembang pada daerah tertentu (Wibowo, 2014). Maka dapat dijelaskan bahwa musik tradisional adalah musik masyarakat yang diwariskan secara turun - temurun dan berkelanjutan pada masyarakat dalam suatu daerah. Maka pengertian musik tradisional adalah cetusan ekspresi perasaan melalui suara atau melalui nada dari alat musik sehingga mengandung lagu atau irama yang diwariskan secara turun temurun dari satu generasi ke generasi berikutnya (Aribawa, 2018).

Mengutip Totok Susanto (2016) kata gamelan berasal dari kata bahasa Jawa "gamel" yang berarti memukul yang diikuti akhiran "an" yang menunjukkan kata benda. Totok Susanto juga mendefinisikan gamelan sebagai satu kesatuan alat musik yang dimainkan bersama dengan alat musik yang terdiri dari: Kendang, Bonang, Bonang Penerus, Demung, Saron, Peking (Gamelan), Kenong \& Kethuk, Slenthem, Gender, Gong, Gambang, Rebab, Siter, Suling. Sedangkan bahan utama dalam perangkat gamelan adalah logam, kayu dan kulit. Mengutip artikel Ganug Nugroho Adi berjudul 'Forging gamelan in Central Java' bahwa terdapat ritual yang dilakukan ahli pembuat gamelan sebelum membuat gamelan. Para ahli pembuat gamelan yang dimaksud adalah pembuat gamelan yang berbahan dasar logam, dalam hal ini adalah gamelan perunggu di Desa Wirun, Kabupaten Sukoharjo. Setelah membaca referensi lain, ternyata topik ritual sebelum pembuatan gamelan bisa dijabarkan lebih lanjut. Penelitian tentang ritual sebelum pembuatan gamelan penting dilaksanakan untuk mengetahui pandangan hidup para ahli pembuat gamelan sebagai orang Jawa dan kaitan pandangan hidup tersebut dengan proses pembuatan gamelan yang memerlukan ritual sehingga proses pembuatan gamelan ini tidak hanya dilihat sebagai proses profan semata tetapi juga suatu proses spiritual. Penelitian ini diharapkan akan menambah khazanah pengetahuan dan kajian tentang gamelan sehingga objek penelitian tidak hanya dilihat dari pemain gamelan saja tetapi juga pembuat alat musik ini (Handayani, 2018).

Setiap alat musik dalam karawitan tersebut tidak hanya sekedar alat musik yang dipukul untuk menghasilkan suara yang indah. Alat musik dalam karawitan tersebut memiliki makna atau nilai-nilai luhur. Makna atau nilai-nilai luhur tersebut diambil dari filosofi nama dan bunyi yang dihasilkan dari masing-masing alat musik karawitan. Berdasarkan hasil wawancara didapatkan data bahwa setiap nama alat musik yang menjadi bagian dari karawitan memiliki arti atau makna yang dapat dijadikan sebagai pedoman dalam kehidupan (Sularso, 2017).

Gamelan Gong Kebyar merupakan kekayaan seni budaya Bali yang sangat berpengaruh dalam seni kerawitan Bali. Gamelan Gong Kebyar merupakan barungan gamelan Bali yang berlaras pelog lima nada yang menciptakan nuansa-nuansa musik kebyar. Metode pembelajaran Gong Kebyar saat ini adalah suatu metode tradisional yang biasa dipakai oleh "penguruk" atau guru gamelan.Metode tradisional ini memerlukan waktu, tempat dan alat untuk berlatih.Dengan pesatnya perkembangan teknologi teknikteknik pembelajaran kini dibuat lebih interaktif.Metode pengajaran secara tradisional bisa diaplikasikan 
pada media yang lebih canggih.Salah satunya adalah penggunaan teknologi multimedia untuk pembelajaran (Ariana, 2015).

Satu paket gamelan dibuat dalam kurun waktu 8 hingga 10 bulan tergantung dari tingkat kesulitan masing-masing gamelan. Satu paket gamelan dikerjakan oleh 1 tim pengrajin yang terdiri dari 10-15 orang. Masing-masing pengrajin dalam tim memiki tugasnya masing-masing, yaitu melakukan pencairan bahan baku timah dan tembaga, melakukan proses pembakaran dan pembentukan gamelan, melakukan pengecekan suaran gamelan, penghalusan bentuk gamelan, dan melakukan pembentukan serta ukiran kayu yang menjadi wadah gamelan. Bahan baku utamagamelan adalah timah dan tembaga. Guna mempercepat proses produksi serta meminimalisasi biaya pencampuran, para pengrajin membeli timah dan tembaga yang sudah dicampur menjadi satu lempengan. Lempengan tersebut dibeli oleh mitra di daerah Solo.

I Wayan Surena merupakan mitra yang merupakan pengrajin sekaligus pemilik Gamelan Gunadi di desa Tihingan. yang juga merupakan produsen gamelan. Mitra ini merupakan masyarakat lokal yang telah lama menggeluti usaha ini. Selain menerima pesanan gamelan, yang bersangkutan juga menerima jasa perbaikan gamelan yang mengalami kerusakan. Beberapa pengrajin gamelan di desa Tihingan termasuk I Wayan Surena masih menggunakan alat tradisional dalam beberapa tahapan proses produksinya. Pengrajin terkadang masih menggunakan alat produksi tradisional seperti alat tiup untuk mengatur besar atau kecilnya pembakaran peleburan bahan baku. Selain itu yang bersangkutan juga masih menggunakan kikir untuk menghaluskan permukaan gamelan gong serta menggunakan alat serut untuk menyelaraskan suara gamelan. Hal tersebut berdampak pada lamanya proses produksi. Proses produksi yang lebih lama akan memakan lebih banyak biaya operasional. Selain itu, penggunaan alat tradisional juga memakan lebih banyak tenaga pengrajin itu sendiri.

Pemilik usaha gamelan juga belum memiliki kemampuan pecatatan keuangan yang memadai. Pemilik usaha hanya mengandalkan catatan yang pada buku yang tidak beraturan. Catatan tersebut digunakan hanya sebagai pengingat, tidak mampu memberikan informasi keuangan yang riil. Terkadang pengrajin juga lupa untuk mencatat pada buku tersebut, sehingga tidak semua transaksi tercatat dengan lengkap. Hal tersebut mengakibatkan mitra mengalami kebingungan ketika melihat pencatatan atas pemasukan, serta pengeluaran uang atas operasional usahanya. Pencatatan keuangan sederhana penting untuk dilakukan agar yang bersangkutan megetahui aliran serta saldo uang usahanya, sehingga keuangan perusahaan dapat dikontrol dan dikelola dengan baik. Para pengrajin juga tidak memiliki strategi pemasaran khusus dalam memasarkan gamelanya. Yang bersangkutan menyatakan bahwa konsumen yang akan langsung mendatangi tempat produksi jika ingin memesan gamelan. Tidak adanya strategi pemasaran mengakibatkan pangsa pasar gamelan ini menjadi lebih terbatas. Hanya masyarakat tertentu saja yang mengetahui lokasi usaha pengrajin ini. Bapak Surena juga menyatakan bahwa beliau hanya berharap informasi mengenai tempat usahanya bisa diketahui oleh masyarakat luas tidak sebatas hanya pelanggan saja. Adapun gambaran pengrajin tersebut adalah sebagai berikut. Hal ini juga mengingat bahwa tingkat pendidikan pengrajin ada pada tingkat sekolah dasar, keterampilan yang bersangkutan dalam melakukan pencatatan keuangan dan memasarkan produk masih rendah. Latar belakang tersebutlah yang membuat pengabdian ini penting untuk dilaksanakan.

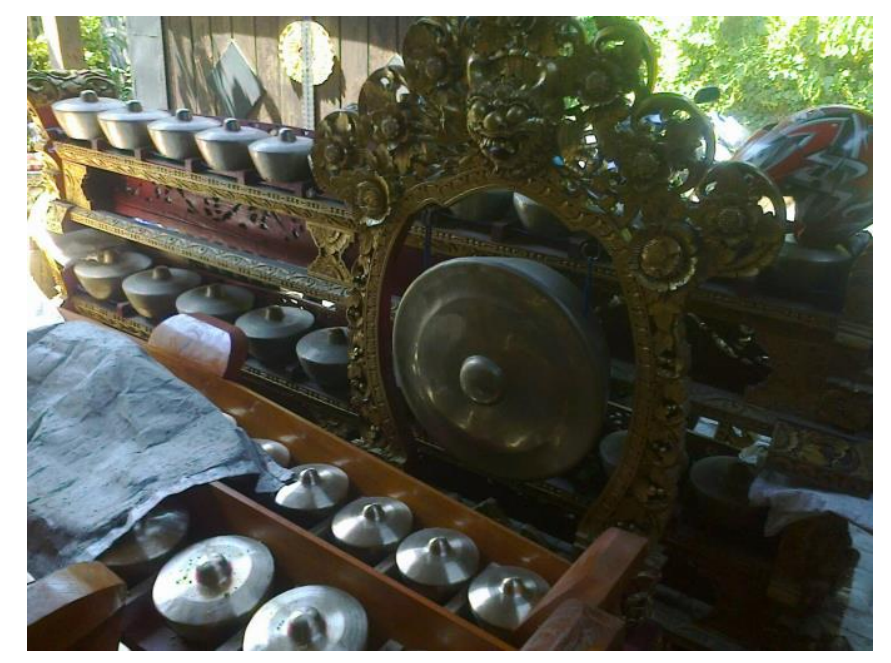

Gambar 1. Gamelan Gong 


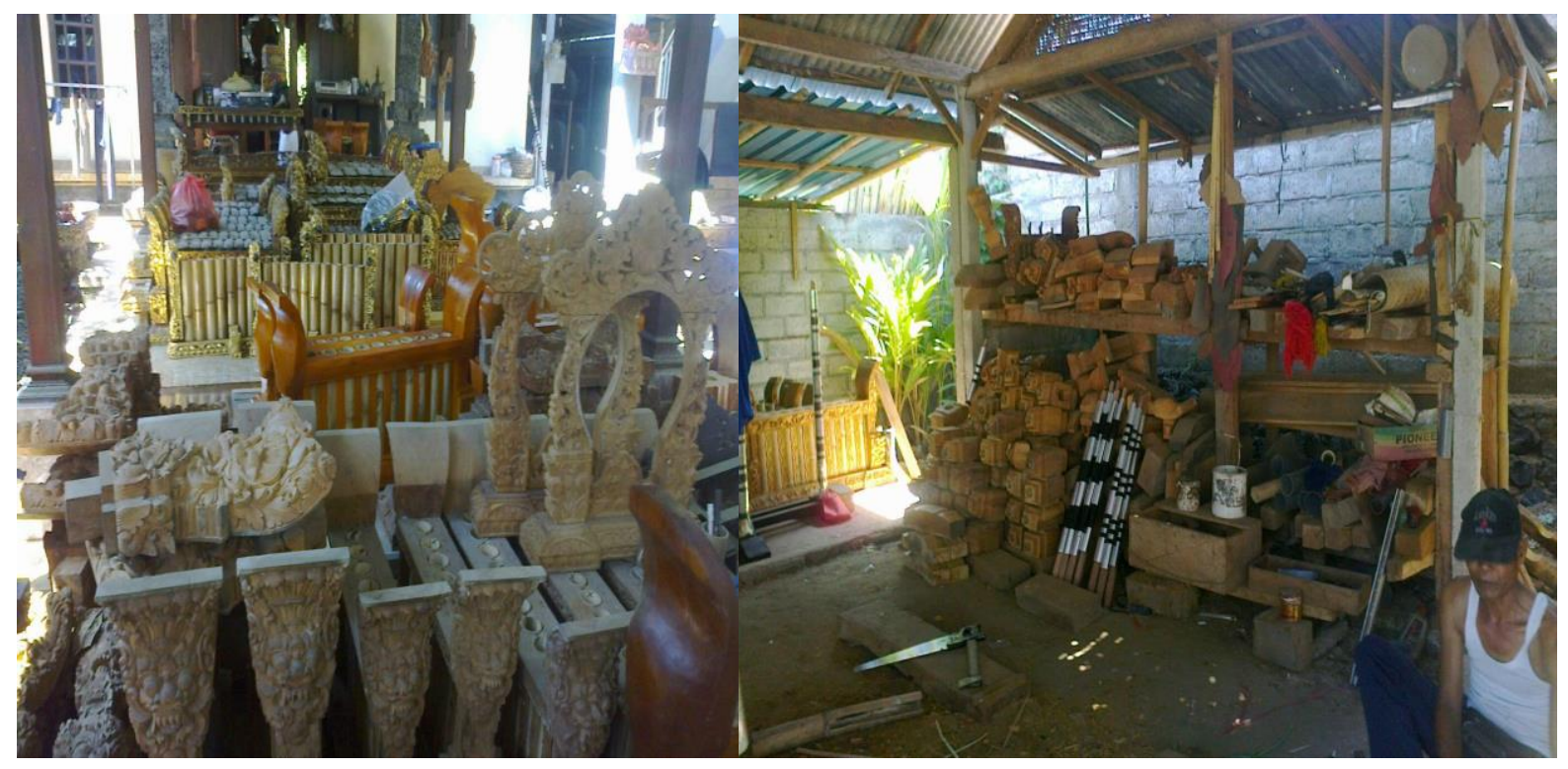

Gambar 2.Tempat Pengrajin Gamelan



Gambar 3. Mitra Pengrajin Gamelan

Permasalahan yang diungkapkan oleh mitra adalah sebagai berikut:

1) Mitra belum memiliki keterampilan yang memadai mengenai pembuatan catatan keuangan sederhana. Dampaknya, pengusaha gamelan belum memiliki rincian penggunaan keuangan sehingga belum dapat mengelola serta mengontrol keuangan usahanya dengan baik. Mitra hanya memiliki catatan pada buku dengan struktur yang tidak beraturan. Bapak Surena menyatakan bahwa catatan atas transaksi tersebut dibuat jika hanya beliau ingat. Hal ini akan berdampak negatif pada kondisi keuangan perusahaan. Mitra tidak memiliki pengetahuan mengenai pemasukan dan pengeluaran kas yang ada pada operasional usahanya.

2) Mitra belum memiliki strategi pemasaran khusus dalam memasarkan produksinya. Bapak Surena hanya mengandalkan para pelanggan sebagai konsumen setianya. Beliau ingin agar pangsa pasar konsumenya lebih meningkat, tetapi tidak paham mengenai strategi apa yang harus diaplikasikan untuk mencapai tujuan tersebut. Konsumen gamelan Bapak Surena terbilang stagnan dalam beberapa tahun terakhir. Sangat kecil jumlah konsumen baru yang ia tangani. Beliau cenderung menangani konsumen lama yang ingin membuat gamelan baru, ataukonsumen lama yang ingin memperbaiki gamelannya yang rusak. Hal tersebut berdampak pada kecilnya ruang lingkup pangsa pasar pengrajin. Kecilnya ruang lingkup pangsa pasar menyebabkan perkembangan usaha menjadi lebih lama. 
Permasalahan yang diungkapkan oleh mitra adalah sebagai berikut:

3) Mitra belum memiliki keterampilan yang memadai mengenai pembuatan catatan keuangan sederhana. Dampaknya, pengusaha gamelan belum memiliki rincian penggunaan keuangan sehingga belum dapat mengelola serta mengontrol keuangan usahanya dengan baik. Mitra hanya memiliki catatan pada buku dengan struktur yang tidak beraturan. Bapak Surena menyatakan bahwa catatan atas transaksi tersebut dibuat jika hanya beliau ingat. Hal ini akan berdampak negatif pada kondisi keuangan perusahaan. Mitra tidak memiliki pengetahuan mengenai pemasukan dan pengeluaran kas yang ada pada operasional usahanya.

4) Mitra belum memiliki strategi pemasaran khusus dalam memasarkan produksinya. Bapak Surena hanya mengandalkan para pelanggan sebagai konsumen setianya. Beliau ingin agar pangsa pasar konsumenya lebih meningkat, tetapi tidak paham mengenai strategi apa yang harus diaplikasikan untuk mencapai tujuan tersebut. Konsumen gamelan Bapak Surena terbilang stagnan dalam beberapa tahun terakhir. Sangat kecil jumlah konsumen baru yang ia tangani. Beliau cenderung menangani konsumen lama yang ingin membuat gamelan baru, ataukonsumen lama yang ingin memperbaiki gamelannya yang rusak. Hal tersebut berdampak pada kecilnya ruang lingkup pangsa pasar pengrajin. Kecilnya ruang lingkup pangsa pasar menyebabkan perkembangan usaha menjadi lebih lama.

Para pengrajin gamelan di Desa Tihingan, Kabupaten Klungkung merupakan masyarakat lokal yang tetap berkarya dengan memproduksi gamelan untuk mempertahankan warisan budaya Bali. Guna mempertahankan eksistensi pengrajin serta meningkatkan produktivitas usahanya, diperlukan beberapa solusi untuk menangani permasalahan yang kerap timbul.

Laporan keuangan menjadi salah satu alat yang dapat digunakan mitra untuk mengetahui kondisi keuangan perusahaan. Melalui penyuluhan ini, mitra diharapkan mampu membuat laporan keuangan sederhana berupa laporan kas harian. Laporan ini dapat memberikan informasi keuangan kepada mitra mengenai aliran uang masuk dan uang keluar pada operasional usahanya. Hal ini dapat dijadikan sebagai alat untuk mengontrol keuangan perusahaan. Catatan kas harian dibuat setiap hari dengan cut off setiap akhir bulan. Pengukuran nilai dan proses terkait solusi permasalahan yang kami tawarkan adalah dengan menilai tingkat pemahaman mitra dalam proses penyusunan catatan kas harian sebelum dan sesudah proses penyulusan diberikan. Peningkatan pengetahuan dan keterampilan mitra usaha terkait penyusunan laporan arus kas menjadi fokus kami. Kecocokan antara saldo kas yang tercatat pada catatan kas harian dengan saldo kas riil menjadi tolak ukur berhasilnya proses penyuluhan ini.

Strategi pemasaran menjadi salah satu aspek penting dalam keberlangsungan suatu usaha. Mitra belum memiliki pengetahuan yang memadai mengenai strategi pemasaran yang harus dijalankan. Penyuluhan ini dapat membantu mitra untuk mengetahui hal-hal penting yang harus dilakukan untuk meningkatkan pangsa pasar sekaligus meningkatkan penjualan produk. Penyuluhan ini dilakukan dengan menentukan bauran pemasaran. Bauran pemasaran dapat disusun dengan memperhatikan empat aspek utama yaitu produk, harga produk, distribusi produk, dan promosi.

Pengukuran nilai dan proses terkait efektifitas solusi permasalahan yang kami tawarkan adalah dengan menilai peningkatan jumlah konsumen sebelum dan sesudah penerapan strategi Word of Mouth. Jangka waktu pengukuran terkait efektifitas penerapan strategi ini adalah setelah selesainya proses pendampingan kegiatan ini dilakukan. Pada tahap awal penerapan strategi pemasaran Word of Mouth ini, kelompok mitra harus menentukan target konsumen yang akan dituju. Beberapa alternatif kami tawarkan misalnya melalui banjar-banjar, sekaa teruna-teruni, melalui agenda kesenian yang diselenggaran di Bali (misalnya Pesta Kesenian Bali). Perwakilan masing-masing kabupaten/kota menjadi target sasaran mitra. Kualitas dan kustomisasi gambelan yang disesuaikan dengan kebutuhan dan selera konsumen menjadi nilai tambah yang dapat ditawarkan mitra usaha. Alasan penekanan kustomisasis gambelan karena pelaku kesenian yang telah berada pada tahap mumpuni (expert), tidak lagi berfokus terkait teknik seni, melainkan lebih kepada ciri khas seni yang menjadi pembeda dengan seniman lain.

\section{Metode}

\section{Penyuluhan Pembuatan Pencatatan Keuangan}

Pada penyuluhan ini, pengusul akan memberikan penjelasan kepada mitra mengenai cara pembuatan catatan keuangan sederhana yang akan dijelaskan oleh ketua dibantu oleh anggota I dan anggota II. Materi penyuluhan meliputi jenis pencatatan keuangan yang dianjurkan untuk dibuat serta cara membuat pencatatan keuangan tersebut. Adapun laporan keuangan yang akan dipaparkan yaitu.

a) Catatan Kas Harian

Catatan kas harian memberikan informasi historis mengenai pemasukan dan pengeluaran kas pada satu hari. Catatan ini dibuat dengan tujuan agar mitra mengetahui saldo awal dan saldo akhir kas 
dalam satu hari. Saldo tersebut kemudian dicocokan dengan jumlah kas yang dibawa oleh mitra, dengan harapan jumlah saldo akhir antara pencatatan dan jumlah saldo riil yang dibawa oleh mitra adalah seimbang (balance) (Ikatan Akuntan Indonesia. 2013).

Setelah materi penyuluhan selesai dijelaskan, maka akan dilanjutkan dengan praktek pembuatan pencatatan keuangan sederhana. Praktek akan dilakukan melalui media buku kas harian yang telah disediakan penulis yang nantinya akan langsung diserahterimakan kepada mitra.

\section{Penyuluhan Strategi Pemasaran}

Strategi pemasaran menjadi salah satu aspek penting dalam keberlangsungan suatu usaha. Strategi pemasaran yang tepat diyakini akan berkontribusi pada peningkatan penjualan. Penyuluhan strategi pemasaran akan dilakukan oleh anggota I, yang akan dibantu oleh ketua dan anggota II. Penyuluhan akan diberikan melalui media presentasi yang disajikan dalam bentuk Power Point. Materi yang akan disampaikan meliputi strategi pemasaran serta strategi promosi. Pertama-tama, mitra akan diberikan informasi mengenai definisi strategi pemasaran serta proses menyusunya. Terdapat tiga aspek penting dalam menyusun strategi pemasaran yaitu.

a) Strategi segmentasi pasar

Pada tahapan ini, mitra bersama penulis membuat daftar kelompok konsumen. Masing-masing kelompok konsumen memiliki kebutuhan dan karakteristik, serta perilaku yang berbeda-beda. Daftar ini dibuat dengan tujuan agar mitra bisa mengetahui gambaran kebutuhan dan perilaku konsumen yang nantinya akan disasar.

b) Strategi penentuan pasar sasaran

Mitra bersama penulis akan membuat ukuran segmen pembeli yang akan disesuaikan dengan kemampuan mitra untuk memasuki segmen tersebut.

c) Strategi penentuan posisi pasar

Strategi ini erat kaitannya dengan cara mitra untuk membangun kepercayaan dan keyakinan konsumen terhadap karakter mitra serta produk yang dihasilkan. Pada tahapan ini, aktifitas utamanya adalah mendesain citra dan memposisikan diri di benak konsumen (Wibowo dkk, 2015).

Materi selanjutnya adalah mengenai promosi. Pada pemaparan materi ini, strategi promosi yang ditawarkan oleh penulis adalah Word of Mouth (WOM). WOM merupakan komunikasi interpersonal antara dua bahkan lebih individu seperti anggota kelompok referensi atau konsumen dan tenaga penjual (Assael, 1995). Setiap orang memiliki pengaruh atas pembelian terus menerus melalui suatu komunikasi. Rekomendasi dari mulut ke mulut merupakan salah satu faktor penting yang berpengaruh terhadap keputusan seseorang dalam membeli suatu produk (Widyaswati, 2010). Strategi ini ditawarkan kepada mitra karena lebih mudah diaplikasikan, lebih efektif dan efisien. berikut.

Pada usulan ini, adapun uraian kepakaran serta tugas masing-masing anggota adalah sebagai

Tabel 1. Uraian Kepakaran

\begin{tabular}{|c|c|c|c|c|}
\hline No. & Nama & Status & Kepakaran & Tugas \\
\hline 1. & $\begin{array}{l}\text { Ni Nyoman Sri Rahayu Damayanti, } \\
\text { SE, M.Si }\end{array}$ & Ketua & Akuntansi Keuangan & $\begin{array}{l}\text { a. Merencanakan } \\
\text { tahapan pengabdian } \\
\text { masyarakat } \\
\text { b. Melakukan } \\
\text { komunikasi dan } \\
\text { koordinasi awal } \\
\text { dengan mitra } \\
\text { c. Menyusun kerangka } \\
\text { proposal } \\
\text { d. Membuat materi } \\
\text { penyuluhan } \\
\text { e. Memberikan materi } \\
\text { penyuluhan }\end{array}$ \\
\hline
\end{tabular}




\begin{tabular}{|c|c|c|c|c|}
\hline 2. & $\begin{array}{l}\text { I Gusti Bagus Ngurah Panji Putra SE, } \\
\text { M.Si }\end{array}$ & $\begin{array}{l}\text { Anggota } \\
\text { I }\end{array}$ & Akuntansi Keuangan & $\begin{array}{l}\text { a. Melakukan } \\
\text { komunikasi dan } \\
\text { koordinasi dengan } \\
\text { mitra } \\
\text { b. Mempersiapkan } \\
\text { alat peraga } \\
\text { presentasi. } \\
\text { c. Memberikan materi } \\
\text { penyuluhan }\end{array}$ \\
\hline 3. & I Gde Agung Wira Pertama, SE, MM & $\begin{array}{l}\text { Anggota } \\
\text { II }\end{array}$ & $\begin{array}{l}\text { Manajemen } \\
\text { Pemasaran }\end{array}$ & $\begin{array}{l}\text { a. Mempersiapkan } \\
\text { kelengkapan sarana } \\
\text { dan prasarana } \\
\text { pengabdian. } \\
\text { b. Membuat materi } \\
\text { penyuluhan } \\
\text { c. Memberikan materi } \\
\text { penyuluhan }\end{array}$ \\
\hline
\end{tabular}

Lembaga pendidikan tinggi di Indonesia diharapkan mengimplementasikan hasil penelitian dalam bentuk pengabdian kepada masyarakat yang sesuai keunggulan potensi wilayah. Bali salah satu tujuan wisata dunia, juga memiliki lembaga pendidikan tinggi swasta terbesar. Visi misi yang dimiliki lembaga tersebut yaitu bermutu, berintegrasi dan berwawasan lingkungan. Rencana strategis yang dirumuskan adalah lembaga pendidikan professional yang siap bersaing ditingkat nasional dan global tahun 2034 . Memiliki 7 program studi (Fakultas Pertanian, Kedokteran, Teknik, Ekonomi, Hukum, Fisip, Sastra) dan 1 Pascasarjana serta mahasiswa berjumlah 8.500.000.000 orang. Riset unggulan institusional yang dibangun berorientasi pada lingkungan berbasis kepariwisataan (Green Eco Tourism). Pengembangan bidang keilmuan didasarkan pada konsep Tri Hita Karana yang diambil dari filosofi budaya masyarakat di Bali yaitu sikap empati terhadap sesama manusia, alam dan Maha Pencipta yang diwujudkan dalam bentuk pengabdian kepada masyarakat.

Terkait dengan tugas pokok dan fungsinya, lembaga pengabdian kepadamasyarakat Universitas Warmadewa (LPM) telah melakukan beberapa kegiatan baik yang dibiayai universitas, pemerintah maupun kerjasama dengan pihak-pihak lain. Anggaran dan perolehanhibah terus mengalami peningkatan. Pada tahun 2010 berhasil memperoleh hibah Dikti sejumlah 5 pengabdian berupa pengabdian Dosen Muda, Kajian Wanita, dan Hibah Kompetitif. Pada tahun 2016 meloloskan 16 proposal pengabdian dan 15 penelitian antar bidang yang didanai lembaga institusi sebesar Rp 160.000.000. Pada tahun 2017 memperoleh dana institusi Rp.250.000.000, per kelompok Rp 12.500.000. Sejumlah 21proposal penelitian dan pengabdian sudah lolos Hibah Dikti.

Dibidang pengabdian yang sifatnya incidental LPM mengadakan kegiatan pengabdian setiap tahun bekerjasana dengan mitra pemerintah, swasta, dan kelompok masyarakat yang didanai bersama, berupa pengabdia antar bidang dan Desa Binaan. Desa Binaan yang sudah di launching adalah desa Pinggan di Kecamatan Kintamani, Kabupaten Bangli. Di Kabupaten Karangasem dengan 8 kecamatan, 38 Desa dengan program KKN: menuntaskan buta aksara, menggali potensi pariwisata, penerapan teknologi tepat guna, serta pemberdayaan masyarakat.

Dalam rangka meningkatkan kualitas dan kuantitas lembaga pengabdian kepada masyarakat LPM menyelenggarakan pelatihan dan pendampingan pembuatan proposal dengan mendatangkan tim reviewer dari Dikti, juga menyelenggarakan pelatihan reviewer internal. Menyelenggarakan seminar nasional penulisan jurnal bereputasi internasional, mengirim beberapa dosen untuk ikut dalam konfrensi tingkat internasional sebagai penyaji karya ilmiah tahun 2016 dan pengembangan inkubator bisnis sebagai penampung hasil produk desa binaan. Adanya Ka Unit Kajian wanita. Ka. Unit lingkungan, dan Ka, unit kajian budaya.

\section{Bidang Sarana}

Sarana penunjang program tridarma yang dimilikilembaga seperti: Laboratorium Biologi, Laboratorium Fisika, Laboratorium Kimia, Laboratorium Basah, Laboratorium Kering, Laboratorium Kedokteran, Laboratorium Teknik, Laboratorium Bahasa, Laboratorium Bantuan Hukum dan Pengadilan Semu, serta Laboratorium Ilmu Sosial dan Ilmu Politik. Agar dapat memberikan jaminan mutu yang tinggi sejalan dengan berkembangnya IPTEK dan kebutuhan kompetensi tenaga kerja di pasar yang terus menerus meningkat dan bervariasi, Maka dalam lima tahun kedepan, Universitas Warmadewa merencanakan untuk melakukan pengembangan terhadap beberapa hal, yaitu: 1) Revtalisasi sarana 
laboratorium/workshop di masing-masing program studi sebagai penunjang mutu pengabdian dan lulusan, 2) Mengembangkan perpustakaan menjadi perpustakaan yang berbasis pada IT (e-library) sehingga mempermudah dalamakses kekinian dari IPTEK, 3) Mengembangkan sarana Tempat UjiKopetensi (TUK) pada masing-masing jurusan, dan 4) Meningkatkan kualitas sarana pembelajaran (media pembelajaran).

\section{Bidang Prasarana}

Ketersediaan prasarana yang dimilikiUniversitas Warmadewa yang digunakan oleh programprogram studi dari aspek kecukupan dipandang telahmemadai sesuai dengan kebutuha dari kompetensi dan profil dar masing-masing program studi, namun demikan sejalan dengan keinginan lembaga dalam beberapa tahun kedepan yang berupaya untuk meningkatan kuantitasdan kualitas pengabdian, maka masih dipandang perlu untuk terus dilakukan penambahan prasarana baru.

Dilihat dari aspek kewajaran, Universtas Warmadewa masih memandang perlu untuk terus melakukan pengembangan. Pengembangan ini dkaitkan dengan relevansinya pengabdian dengan kebutuhan industri dan sejalan pula dengan perkembangan IPTEK menjadi dasar acuan bagi lembaga dalam menjaga kewajaran dan kecukupan prasarana yang harus disediakan dalam program-program studi. Rencana pengembangan dalam lima tahun ke depan terhadap prasarana, akan melakukan pengembangan prasarana dengan melihat pada kebutuhan kompetensi dan perkembangan teknologi yang ada. Pengembangan akan dilakukan terkait dengan kebutuhan program studi terhaadap ketersediaan prasarana di kelas, laboratorium, maupun kebutuhan di workshop. Sasaran pengembangan dalam prasarana adalah semakin meningkatnya mutu hasil pengabdian, pelayanan yang berkualitas terhadap riset dan relevansi kompetensi riset.

\section{Hasil dan pembahasan}

Berdasarkan Persiapan awal dilakukan dengan membuat jadwal pelaksanaan kegiatan yang nantinya akan disepakati antara mitra dengan penulis. Setelah tercapai kesepakatan, ketua dan masingmasing anggota membuat materi penyuluhan yang akan disampaikan kepada mitra. Ketua dan anggota I membuat materi penyuluhan serta buku praktik mengenai tata cara pembuatan catatan keuangan sederhana sedangkan anggota II membuat materi penyuluhan mengenai stratgei pemasaran yang efektif dan efisien. Setelah itu, penulis mempersiapkan sarana lainnya yang akan digunakan untuk menunjang pelaksanaan pengabdian seperti alat tulis, kalkulator, kertas HVS, kamera, laptop, serta kendaraan.

Pelaksanaan kegiatan dimulai dengan melakukan pertemuan dengan mitra untuk mempersiapkan lokasi acara dan sarana yang dibutuhkan pada saat penyampaian materi. Penyampaian materi mengenai penyuluhan catatan keuangan dilaksanakan oleh ketua dibantu dengan anggota I. Setelah itu, dilanjutkan dengan praktik penyusunan catatan keuangan sederhana. Praktik penyusunan dipandu secara langsung oleh anggota I dengan menggunakan sarana bantuan buku kas harian yang telah dipersiapkan sebelumnya. Mitra diajarkan untuk mencatatn transaksi keuangannya setiap hari pada buku tersebut. Buku catatan kas harian dibedakan menjadi 2, yaitu buku catatan kas harian dan buku catatan kas pada bank harian. Buku catatan kas harian digunakan untuk mencatat seluruh transaksi yang berkaitan dengan perubahan nilai cash on hand sedangkan buku catatan kas bank harian digunakan untuk mencatat seluruh transaksi yang berkaitan dengan perubahan nilai kas pada rekening bank. Buku catatan ini dibedakan dengan tujuan untuk mengetahui nilai cash on hand yang dimiliki mitra dan nilai kas pada bank. Pencatatan keuangan harian ini dapat membantu mitra untuk mengetahui aliran dana serta saldo dana yang dimiliki. Pencatatan ini juga akan mempermudah mitra untuk melakukan perencanaan keuangan untuk produksi selanjutnya karena telah mengetahui saldo dana yang tersisa.

Pelaksanaan selanjutnya yaitu dengan memberikan penyuluhan mengenai strategi pemasaran yang efektif dan efisien bagi mitra. Strategi pemasaran dipilih berdasarkan atas diskusi yang sebelumnya telah dilakukan antara mitra dengan anggota II. Mitra menginginkan strategi pemasaran yang tidak menghabiskan banyak biaya serta mudah untuk diimplementasikan. Word of mouth adalah strategi pemasaran yang telah dipilih dan telah dijelaskan pula definisi serta tata cara pengimplementasiannya oleh anggota II. Word of mouth adalah strategi pemasaran yang menekankan pada penyampaian penilaian seseorang mengenai suatu produk atau jasa. Strategi ini dilakukan dengan menyampaikan penilaiannya dari mulut ke mulut. Apabila konsumen merasa puas dengan produk atau jasa yang telah dikonsumsi, maka yang bersangkutan dianjurkan atau diminta untuk menyampaikan hal tersebut kepada individu lain. Hal ini dilakukan agar individu lain tertarik dan terpengaruh untuk turut serta mengkonsumsi barang atau jasa tersebut. Apabila konsumen merasa kurang puas terhadap suatu produk atau jasa dan ingin memberikan kritik serta saran, mereka diminta untuk tidak menyampaikan hal tersebut pada individu lain melainkan menyampaikan hal tersebut pada perusahaan yang bersangkutan. Hal ini dilakukan agar 
perusahaan bisa melakukan perbaikan atas kekurangan dari produk atau jasa yang dihasilkan. Adapun beberapa dokumentasi ketika pelaksanaan penyuluhan berlangsung yaitu sebagai berikut.
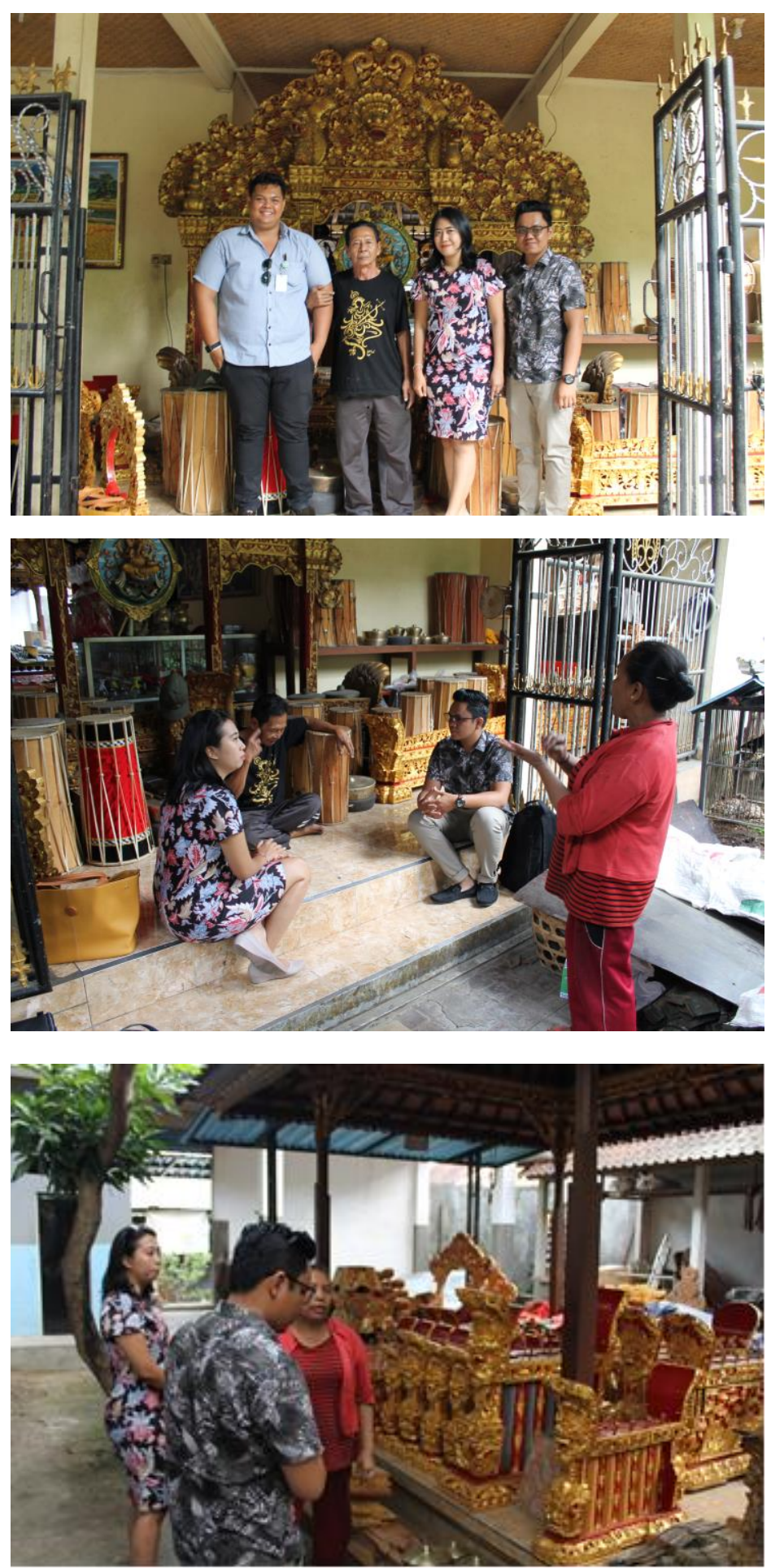

Gambar 4. Pelaksanaan penyuluhan

Berdasarkan atas penyuluhan serta pelatihan yang telah diberikan kepada mitra, dirasa perlu adanya keberlanjutan program untuk memperkuat kemampuan mitra dalam penyusunan catatan keuangan serta mengimplementasikan strategi pemasaran. Adapun rencana tahapan berikutnya yang akan dilaksanakan adalah sebagai berikut.

1. Mitra dianjurkan untuk membuat catatan daftar hutang dan piutang dagang. Catatan daftar hutang dan piutang dagang dibuat untuk mempermudah mitra mengetahui total nilai hutang yang menjadi 
kewajiban mitra serta nilai piutang yang menjadi hak mitra. Catatan ini dapat mempermudah mitra untuk melakukan penagihan piutang secara teratur. Selain itu, yang bersangkutan juga dapat melakukan pembayaran hutang dagang secara tepat waktu tanpa harus terkena denda atau pinalti.

2. Melakukan kerjasama antara pengusul dengan ahli Informasi dan Teknologi (IT) untuk membantu mitra membuat website yang didalamnya berisikan mengenai informasi umum dan khusus mengenai perusahaan dan produk yang dihasilkan. Hal tersebut dilakukan sebagai upaya untuk memperkenalkan perusahaan sekaligus memasarkan produk kepada masyarakat, dengan harapan dapat meningkatkan penjualan mitra. Penggunaan website sekaligus mendukung strategi pemasaran word of mouth yang sebelumnya sudah dijalankan.

\section{Simpulan dan saran}

Berdasarkan atas kegiatan yang telah dilaksanakan, dapat disimpulkan bahwa.

1. Mitra usaha Gamelan Gunadi mengalami kesulitan pada saat melakukan pencatatan keuangan perusahaan serta saat melakukan pemasaran produknya. Hal tersebut melatarbelakangi pengusul untuk melaksanakan kegiatan pengabdian berupa penyuluhan mengenai pembuatan catatan keuangan sederhana serta penyuluhan mengenai strategi pemasaran.

2. Penyuluhan dan praktik pembuatan pencatatan keuangan sederhana telah dilakukan dengan bantuan buku kas on hand harian dan buku kas bank harian yang telah dibuat oleh pengusul. Mitra telah mampu mencatat transaksi harian pada media yang telah diberikan. Bahasa pencatatan dibuat sederhana agar mitra lebih mudah dalam membuat catatan.

3. Penyuluhan mengenai strategi pemasaran telah dilakukan dengan metode ceramah dan diskusi. Strategi word of mouth dipilih karena dirasa sesuai dengan kebutuhan mitra. Mitra dapat dengan mudah mengimplementasikan strategi ini karena dianggap efektif dan efisien. Konsumen yang merasakan kepuasan pada pelayanan dan produk yang dihasilkan mitra, dapat menyampaikan hal tersebut pada individu lain, dengan harapan individu tersebut memiliki informasi positif mengenai mitra dan produk yang dihasilkan. Hal ini diharapkan dapat mendorong individu tersebut untuk turut serta menggunakan produk yang dihasilkan mitra. Konsumen yang merasakan ketidakpuasan pada pelayanan dan produk yang dihasilkan mitra dapat langsung menginformasikan kritik serta sarannya pada mitra, bukan pada individu lain. Hal ini dilakukan agar mitra dapat dengan cepat melakukan proses evaluasi.

Pelaksanaan pengabdian ini diharapkan dapat menyasar mitra lain dengan usaha sejenis. Usaha gamelan merupakan usaha rumahan yang cenderung masih bersifat tradisional tanpa pencatatan keuangan dan strategi pemasaran yang baik. Memiliki potensi pengembangan usaha yang tinggi, perlu bagi mitra untuk memiliki kompetensi yang memadai. Selain dari bidang keuangan dan pemasaran, para mitra juga peru diberikan penyuluhan dari segi aspek hukum terutama mengenai ijin usaha dan paten produk.

\section{Daftar Rujukan}

Assael, Henry. 1995. Costumer Behavior and Marketing Action, Keat Publishing Company, Boston.

Aribawa, Komang. 2018. Pengembangan Aplikasi Game Musik Tradisional Bali Megamelan Berbasis Multiplatform . Jurnal Teknologi Informasi dan Ilmu Komputer (JTIIK).

Ariana, A.A. Gede Bagus. 2015. Rancang Bangun Media Pembelajaran Alat Musik Gamelan Gong Kebyar Berbasis Android . Jurnal S@CIES Volume 5, Nomor 2, April 2015

Davison, G. dan C Mc Conville. 1991. A Heritage Handbook. St. Leonard, NSW: Allen \& Unwin.

Handayani, Andri. 2018. Ritual Pembuatan Gamelan Di Desa Wirun, Kabupaten Sukoharjo . Jurnal Gama Societa, Vol. 2 No. 1, Mei 2018

Hawkins, P. 2012. Creating a Coaching Culture. New York: Bell and Bain Ltd. Diakses 2 Februari 2019 dari http://goo.gl/8Kd6Jo.

Ikatan Akuntan Indonesia. 2013. Standar Akuntansi Keuangan Entitas Tanpa Akuntabilitas Publik (SAK ETAP). Jakarta: Ikatan Akuntan Indonesia. 
Sularso, Pryo. 2017. Upaya Pelestarian Kearifan Lokal Melalui Ekstrakurikuler Karawitan Di Smp Negeri 1 Jiwan Tahun 2016. Jurnal Pendidikan Pancasila dan Kewarganegaraan Vol 5 No 1 April 2017

Widyaswati, Rahmatya. 2010. Analisis Faktor-Faktor Yang Mempengaruhi Kepuasan Sehingga Tercipta Word of Mouth Yang Positif Pada Pelanggan Speedy Di Semarang.

Wulandari, Anak Agung Ratih. 2017. Pengaruh Modal, Tenaga Kerja, Dan Lama Usaha Terhadap Pendapatan Pengrajin Industri Kerajinan Anyaman Di Desa Bona Kecamatan Blahbatuh Kabupaten Gianyar . E-Jurnal Ekonomi Pembangunan Universitas Udayana Vol.6, No.4 April 2017 